\title{
Accuracy of frozen-section combined with imprint and fine needle aspiration biopsy in thyroid nodules
}

\author{
Benyamin Makes
}

\begin{abstract}
Abstrak
Keganasan tiroid dapat ditemukan sekitar 5\% dari kasus dengan nodul tiroid. Untuk penatalaksanaan kasus nodul tiroid perlu membedakan kasus jinak dari yang ganas. Biopsi aspirasi jarum halus (BAJaH) dilakukan praoperasi sedangkan potong beku dilakukan pada saat operasi. Tujuan tulisan ini ialah mengevaluasi ketepatan diagnosis pemeriksaan BAJaH serta PB bersama sitologi imprint $(P B+I)$ pada kasus-kasus nodul tiroid di Departemen Patologi Anatomik FKUI-RSCM. Penelitian ini merupakan uji diagnostik menggunakan data arsip klinikopatologik di Departemen Patologi Anatmik FKUI-RSCM selama tahun 1999-2003. Spesimen dengan kelengkapan data hasil pemeriksaan BAJaH; data hasil pemeriksaan potong beku disertai sediaan sitologi imprint, serta sediaan histologik terfiksasi formalin dari bahan biopsi / operasi tiroid yang sama, digunakan dalam penelitian ini. Sensitivitas, spesifisitas dan akurasi PB+I lebih tinggi daripada BAJaH (berturut-turut $86,8 \%$ vs 73,7\%;99,0\% vs 83,9\%;94,8\% vs $80,5 \%$ ). Bila hasil BAJaH konkordan dengan hasil PB+I, akurasi gabungan ke dua pemeriksaan tersebut menjadi 95,1\%. Evaluasi potong beku bersama sitologi imprint masih sangat bermanfaat, karena pemeriksaan ini secara bermakna menunjukkan akurasi yang tinggi dalam mendiagnosis keganasan tiroid. (Med J Indones 2007; 16:89-93)
\end{abstract}

\begin{abstract}
Thyroid malignancy can be found on $5 \%$ of thyroid nodules. In order to better managed of thyroid nodules, skills to differentiate benign from malignant cases were needed. Fine needle aspiration biopsy (FNAB) was done preoperatively while frozen section (FS) and imprint cytology (IC) should be done intra-operatively. The objective of this research paper is to evaluate the diagnostic accuracy of FNAB versus frozen section combined with imprint cytology $(F S+I C)$ in thyroid nodules at the Anatomic-Pathology Department FMUI-CM Hospital, Jakarta. This diagnostic test, used data from clinico-pathological records in Anatomic Pathology Department, Faculty of Medicine University of Indonesia / Dr. Cipto Mangunkusumo General Hospital, Jakarta, Indonesia during 1999-2003. Specimens with complete data of FNAB results, data of FS and slides of IC. All formalin fixed'specimens were reevaluated and used as the golden standard. Sensitivity, spesificity and accuracy of FS+IC were higher than FNAB (86.8\% vs $73.7 \% ; 99.0 \%$ vs $83.9 \%$; $94.8 \%$ vs $80.5 \%$ respectively). If the results of FNAB were concordant with the result of FS+IC, the combined examination yields accuracy of $95.1 \%$. The evaluation of frozen section combined with imprint cytology is very useful, because this examination significantly showed high accuracy in diagnosing thyroid malignancy. (Med J Indones 2007; 16:89-93)
\end{abstract}

Keywords: thyroid nodules, FNAB, frozen section, imprint cytology, accuracy

Thyroid nodules detected clinically were found in 4-7\% adult patients, while 5\% among them were malignant. Although thyroid function test, scintigraphy, and ultrasound were routinely used for diagnosing thyroid nodules, they could not discriminate between benign and malignant lesions. ${ }^{1}$

In some studies, sensitivity of frozen section (FS) for diagnosis of thyroid carcinoma were only $60 \%$ to

Endocrine Division, Anatomic-Pathology Department, Faculty of Medicine University of Indonesia/ Dr. Cipto Mangunkusumo

General Hospital, Jakarta, Indonesia
$70 \% .^{2}$ The accuracy of intra-operative diagnosis was increased to $99 \%$ if the FS procedure was in combination with imprint cytology (IC). ${ }^{3}$ Taneri et al found that sensitivity of FS if combined with IC was $96 \%$, and the specificity was $96 \%$. $^{1}$ The specimen of imprint cytology could give a features of cells with size and shape similar to the origin, so it could be used as an aid for intra-operative diagnosis of FS. This method could optimized the cellular detail preservation, and was considered relative easier than FS. ${ }^{3}$

Fine needle aspiration biopsy (FNAB) of thyroid nodules yield sensitivity in the range of $65-98 \%$ and specificity of $73-100 \%$. Some studies showed that 
FNAB was considered as the most accurate, costeffective, simple, with slight possibility of complication. However, FNAB had limitations in relation to the specimen adequacy, the physician's skill who performed the aspiration, the experience of the pathologist in the specimen interpretation, and the overlapping of cytologic features between benign and malignant follicular neoplasia. ${ }^{4}$ Although FNAB was the first significant diagnostic step, it would be better if the negative results of FNAB should not exclude the malignancy if it was suspicuous clinically. ${ }^{5}$

The aim of this study was to evaluate the diagnostic accuracy of FNAB versus frozen section combined with imprint cytology in thyroid nodules at the Anatomic-Pathology Department Faculty of Medicine University of Indonesia - Dr. Cipto Mangunkusumo Hospital, Jakarta

\section{METHODS}

This study used a diagnostic test design. It can be considered as a real world research because it was conducted in natural settings of everyday clinical practice. The medical records of subjects with thyroid nodule who underwent pathologic examination at Anatomic- Pathology Dept. Faculty of Medicine University of Indonesia - Dr. Cipto Mangunkusumo General Hospital Jakarta during the year of 1999-2003 were reviewed. All subjects with complete data of FNAB results, data of FS and slides of IC, and slides of formalin fixed histological specimen were included in this study. The paraffin slides were reevaluated. The histologic findings of formalin fixed specimen were used as the golden standard.

The results of FNAB were categorized as benign, malignant, suspicious, and inconclusive; while the results of FS combined with IC were categorized as positive, negative, and deferred. Deferred meant that the result would be given after the paraffin examination. The malignant result of FNAB meant that the cells of the sample and the process were representative enough and adequate, and also the sign of malignancy were complete; benign, if the aspirate had enough cells but without signs of malignancy; suspicious, if the specimen showed many signs of malignancy but not complete enough; inconclusive, if there were only mild cells changes in the specimen. ${ }^{6}$ The formalin fixed specimen was positive (malignant) if it showed histopathological signs of malignancy; and negative (benign) if there were no sign of malignancy.
Data analysis was performed using JavaStat-2 way contingency table analysis, which yield the sensitivity, specificity, and accuracy of each diagnostic test. The data of FS in combination with IC were compared with final formalin fixed specimen, in two classifications, i.e. only malignant and benign results; and then the deferred results were grouped together with the benign. Similarly for the FNAB data. First, only malignant and benign results were included in the analysis comparing with the histopathological diagnosis of formalin fixed specimen; secondly, the inconclusive results were included in the benign group, while the suspicious were grouped as malignant.

\section{RESULTS}

Among all subjects with thyroid nodule recorded in the clinicopathological data between 1999 - 2003, only 190 that can be included in this study. The results of final histopathologic findings were 62 cases of malignant thyroid nodules and 128 benign cases. Papillary carcinoma of the thyroid was the most common malignancy $(69.36 \%)$, followed by follicular carcinoma $9.68 \%$; anaplastic carcinoma $8.06 \%$; insular carcinoma $6.45 \%$; malignant lymphoma $3.23 \%$; Hurthle cell carcinoma $1.61 \%$; and plasmacytoma also $1.61 \%$. From the benign group, the most common type was adenomatous goiter $(90.63 \%)$, followed by thyroiditis $4.69 \%$, adenoma thyroid $2.34 \%$; and $0.78 \%$ each for degeneration cyst, hemorrhagic cyst, and amyloid goiter.

Follicular lesions were the most common cause of deferred specimen of FS+IC (Table 1), while the inconclusive atypical cell were the most common findings of the inconclusive results of FNAB (Table 2).

Table 1. Results of 40 deferred specimens from Frozen section combined with imprint cytology

\begin{tabular}{lc}
\hline Final histopathology & $\mathrm{n}$ \\
\hline Adenomatous goiter & 22 \\
Adenomatous goiter + papillary hyperplasia & 4 \\
Follicular adenoma & 2 \\
Hurthle cell adenoma & 1 \\
Follicular carcinoma & 2 \\
Papillary carcinoma & 5 \\
Insular carcinoma & 1 \\
Hemorrhagic cyst & 1 \\
Chronic thyroiditis & 1 \\
Plasmacytoma & 1 \\
\hline
\end{tabular}


Table 2. Results of 21 inconclusive specimens from fine needle aspiration biopsy

\begin{tabular}{lc}
\hline Final histopathology & $\mathrm{n}$ \\
\hline Adenomatous goiter & 12 \\
Adenomatous goiter + atypical cell & 1 \\
Adenomatous goiter + papillary hyperplasia & 1 \\
Degeneration cyst & 1 \\
Follicular adenoma & 1 \\
Papillary carcinoma & 2 \\
Follicular carcinoma & 2 \\
Hurthle cell carcinoma & 1 \\
\hline
\end{tabular}

Result of FNAB and the result of FS+IC compared with final histopathological diagnosis can be seen in the Table 3. Comparative analysis between FS+IC and FNAB were done in two ways. First, the analysis were done only for the malignant and benign cases. It was shown that FS+IC yield better results than FNAB. After the deferred were grouped as benign in $\mathrm{FS}+\mathrm{IC}$, and in FNAB the inconclusive were included in the benign group while the suspicious were grouped as malignant, still we can see that the results of FS+IC were higher than the FNAB (table 4). If the FNAB were combined with FS+IC then compared with the final diagnosis, if both the results are concordant $(\mathrm{B} / \mathrm{B}$ and $\mathrm{M} / \mathrm{M})$, the accuracy was $95.1 \%$, higher than if the 2 diagnostic methods were analysed separately.

Table 3. Result of fine needle aspiration biopsy, frozen section + imprint cytology examination compared with final histopathology of formalin fixed specimens

\begin{tabular}{lcc}
\hline & \multicolumn{2}{c}{ Final histopathology } \\
\cline { 2 - 3 } & $\begin{array}{c}\text { Benign } \\
(\mathrm{n}=128)\end{array}$ & $\begin{array}{c}\text { Malignant } \\
(\mathrm{n}=62)\end{array}$ \\
\hline Benign & 94 & 15 \\
Malignant & 13 & 41 \\
Suspicious & 5 & 1 \\
Inconclusive & 16 & 5 \\
Benign & 96 & 7 \\
Malignant & 1 & 46 \\
Deffered & 31 & 9 \\
\hline
\end{tabular}

Table 4. Comparative analysis of fine needle aspiration biopsy, frozen section combined with imprint (FS+IC), and histopathologic diagnosis of thyroid nodules

\begin{tabular}{lcc}
\hline & $\begin{array}{c}\text { FNAB } \\
(\mathrm{n}=169)\end{array}$ & $\begin{array}{c}\text { FS + IC } \\
(\mathrm{n}=150)\end{array}$ \\
\hline Sensitivity & $73.7 \%$ & $86.8 \%$ \\
Specificity & $83.9 \%$ & $99.0 \%$ \\
Positive predictive value & $70.0 \%$ & $97.9 \%$ \\
Negative predictive value & $86.2 \%$ & $93.4 \%$ \\
Accuracy & $80.5 \%$ & $94.8 \%$ \\
\end{tabular}

This study tried to analyze the results of FNAB examination, each for the malignant findings, benign, inconclusive and suspicious. From 54 malignant results of FNAB, 39 malignancy could be detected by FS+IC, but the final diagnosis showed 41 malignancy. The 109 benign lesions of FNAB, could be confirmed as true benign in 94 formalin fixed specimens. Most of the suspicious lesions were proved as benign cases ( 5 of 6 cases). From 3 cases suspiciously malignant of FNAB and benign of FS+IC, all were proved to be benign. The 16 non-follicular lesions from the inconclusive lesions of FNAB, could be confirmed as benign in 13 cases, and as malignant in 3 cases. From 6 inconclusive cases of FNAB and deferred of FS+IC, 1 case was proven to be malignant (follicular carcinoma).

\section{DISCUSSION}

The ability to differentiate malignant nodules from benign nodules of the thyroid was the main problem in the field of thyroid surgery. The most important limitation of FNAB was its ability to diagnose the folicullar lesions. Besides that, also its dependency on the experience of the physician who performed this method, and the clinical interpretation of the results could influence the diagnosis. On the other hand, FS could not be more accurate in differentiate follicular carcinoma from adenoma intra-operatively. ${ }^{7}$ FNAB was currently considered more sensitive and FS was more specific in diagnosing malignant neoplasma. The main role of FNAB was in patient selection for surgery, so the high sensitivity was much needed. Since FS was done in planning the extension of the surgery, it needed high specificity. ${ }^{8}$ This study showed 
that the sensitivity, specificity, positive predictive value, negative predictive value, and accuracy of FS in combination with IC were higher than FNAB.

Determinations of sensitivity and diagnostic accuracy are affected by how the author of a given study chooses to define and classify suspicious FNAB results. Previous studies have shown that the inclusion of suspicious FNAB diagnoses to the malignant group tend to increase the sensitivity of FNAB for detecting thyroid cancer, while decreasing the specificity and overall accuracy of the test. ${ }^{9}$ In contrast with this study, which showed increase specificity and decreasing sensitivity after the suspicious were included in the group of malignant. Similarly in FS+IC, after the deferred were grouped together with the benign, there were decreasing of sensitivity and accuracy (table 2).

There were some studies about the accuracy of FS and or FNAB in diagnosing thyroid malignancy reported in the literature. Study of FS combined with imprint was done by Caraci $e t a l^{8}$, and gave a sensitivity of $80 \%$, lower than this study $(86.8 \%)$ but similar specificity (99\%). Mandell et al, ${ }^{9}$ excluded the deferred in his analysis, so the sensitivity of his study was $96 \%$, much higher than this study, with the specificity of $100 \%$. Ersoy et al, done his study prospectively in Ankara, Turkey, with the sensitivity of FS was very low (54\%) but the specificity were good $(100 \%) .^{7}$ The accuracy of FS in thyroid nodules ranged between $91.7 \%-95 \%,{ }^{7-10}$ while this study yielded $94.7 \%$ for the accuracy of FS.

Studies about FNAB for thyroid nodules, gave a varied result. Mandell et al ${ }^{9}$ analyzed only for true malignant and benign FNAB, showed the sensitivity of FNAB was $89 \%$ and the specificity was $97 \%$, in contrast with this study (sensitivity $73.2 \%$ and specificity $87.9 \%$ ). The specificity of FNAB in a study conducted in Italy was only $45 \%$, with the overall accuracy of $53 \% .{ }^{8}$ Other studies showed varying sensitivities, ranged $27 \%-89 \%$. $^{7-10}$

The present study and earlier studies conducted in Dr. Cipto Mangunkusumo Hospital were also compared. Since 1985, study done by Ramli about FS without imprint cytology for thyroid nodules, showed a sensitivity of $78.9 \%$ and specificity of $98.9 \% .^{11}$ Study done in 2001-2002 by Damanik, FS in combination with IC, showed sensitivity of $68 \%$ and specificity of $91.4 \%$ (deferred were grouped as benign). ${ }^{13}$ Kuntjoro and Makes, in their study during 1990-1991 showed higher sensitivity and specificity, $92.6 \%$ and $98.1 \%$ respectively. ${ }^{12}$ In this study, the sensitivity, specificity and accuracy of FS+IC were higher than FNAB, while Damanik's study gave a similar result between FNAB and FS+IC. ${ }^{13}$

The optimal design for assessing the accuracy of diagnostic test is considered to be a prospective blind comparison of the test and the reference test in a consecutive series of patients from a relevant clinical population. Selection bias can be present when not all patients presenting with the relevant condition are included in order of entry (consecutive) into the study. ${ }^{14}$

In this study the study subjects were histopathologic specimens. The subject would be selected if there were completeness of the data and specimen of FNAB, FS+IC, and the paraffin specimen.

The limitations of this study were in the design, which was done retrospectively, and the way the subjects included in the study (by convenience sampling) with complete relevant data .

\section{CONCLUSION}

Frozen section in combination with imprint cytology was still necessary because of its high accuracy in diagnosing thyroid malignancy. It was also very useful for the surgeon in determining the extent of surgery.

\section{Acknowledgement}

The author thanks Prof. Bastaman Basuki for reviewing early drafts.

\section{REFERENCES}

1. Taneri F, Poyraz A, Salman B, Tekin E, Arkyuerek N, Bayram O, Onuk E. Using imprint and frozen section in determining the surgical strategies for thyroid pathologies. Endocrine Regulations. 2001;35:71-4.

2. Cerovic S, IgnBatovic M, Brajuskovic G, Knezevic-Usaj S, Dimitrijevic J, Cuk V. The value of intra-operative diagnosis in thyroid surgery. Arch Oncol. 2004; 12(Suppl 1):48.

3. Scopa CD, Melachrinon M, Apisson D, Bonilios D. Tissue imprint in surgical pathology: a rapid intraoperative diagnostic aid. Diagn Cytopathol. 1990; 6:5-8.

4. Amrikachi M, Ramzy I, Rubenfeld S, Wheeler TM. Accuracy of fine-needle aspiration of thyroid. Arch Pathol Lab Med. 2001; 125:484-8.

5. Muro-Cacho $\mathrm{CA}, \mathrm{Ku} \mathrm{KNN}$. Tumors of the thyroid gland: histologic and cytologic features. Part 2. Cancer Control. 2000; 7:377-85 
6. Kini SR. Guides to clinical aspiration biopsy. Thyroid. New York; Igaku-Shoin, 1987. p.1-2.

7. Ersoy E, Taneri F, Tekin E, Poyraz A, Cihan A, Dursun A, Onuk E. Peropererative fine-needle aspiration cytology versus frozen section in thyroid surgery. Endocrine regulations. 1999;33:141-4.

8. Caraci P, Aversa S, Mussa A, Pancani M, Ondolo C, Conticello $\mathrm{S}$. Role of fine-needle aspiration biopsy and frozensection evaluation in the surgical management of thyroid nodules. British Journal of Surgery. 2002; 89:797-801.

9. Mandell DL, Genden EM, Mechanick JI, Bergman DA, Biller HF. Diagnostic accuracy of fine-needle aspiration and frozen section in nodular thyroid disease. Otolaryngol Head Neck Surg. 2001;124:531-6.

10. Duek SD, Goldenberg D, Linn S, Krausz MM, Hershko DD. The role of fine-needle aspiration and intra-operative frozen section in the surgical management of solitary thyroid nodules. Surg Today. 2002;32:857-61.

11. Ramli M, Kamajaya. The management of thyroid carcinoma in Head, Neck, and Breast Division, Surgery Department FMUI. Semarang, $6^{\text {th }}$ Annual Scientific Meeting PERABOI, 13-14 November 1990.

12. Kuntjoro, Makes B. Diagnostic accuracy of frozen section in various thyroid disorders as compared with paraffin section from the same cases. Med J Indones. 1995; 4:53-7.

13. Damanik R. Accuracy of clinical examination, ultrasound, and fine needle aspiration biopsy of thyroid nodules. Thesis. FMUI, Jakarta, 2003.

14. Lijmer JG, Mol BW, Heisterkamp S, Bonsel GJ, Prins MH, van der Meulen JHP, et al. Empirical evidence of design-related bias in studies of diagnostic tests. JAMA. 1999; 282:1061-6. 